
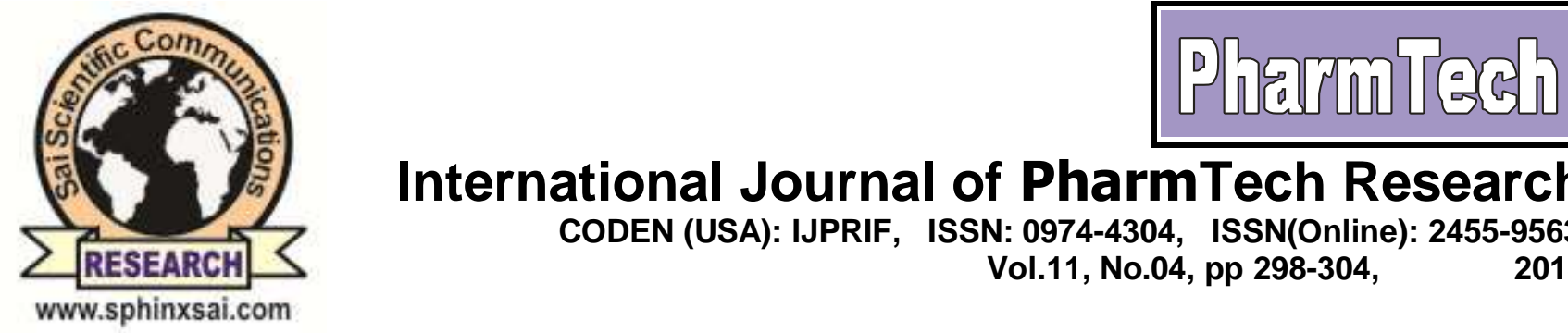

International Journal of PharmTech Research CODEN (USA): IJPRIF, ISSN: 0974-4304, ISSN(Online): 2455-9563

Vol.11, No.04, pp 298-304,

2018

\title{
White Blood Cell Count Mean Platelet Volume Ratio as A Predictor of Major Adverse Cardiovascular Event in Acute Non St-Elevation Myocardial Infarction (NSTEMI)
}

\author{
Yusrina Saragih*1, Ali N. Nasution ${ }^{1}$, Cut A. Andra ${ }^{1}$, Harris Hasan ${ }^{1}$, \\ Abdul Halim $\mathbf{R}^{1}$, Zainal Safri ${ }^{1}$ \\ ${ }^{1}$ Department of Cardiology and Vascular Medicine, University of Sumatera Utara, \\ Adam Malik Hospital, Medan, Indonesia
}

\begin{abstract}
Background :Recent studies have shown that complete blood count analysis can become a strong parameter to predict long term complication and reinfarction in acute coronary syndrome (ACS) but there are still no parameter known for predicting short term and inhospital complication. White Blood Cell Count Mean Platelet Volume Ratio (WMR) is one of parameter from complete blood count analysis that can be used for predicting Major Adverse Cardiovascular Event (MACE) that has not been studied extensively. The main objective of this study is to determine whether WMR can be used as a MACE predictor for NSTEMI patient during hospitalization.

Method :A total of 104 patients with NSTEMI who undergo treatment at Haji Adam Malik Hospital since October 2017 until April 2018 were recruited in this prospective cohort study. The relationship of baseline White Blood Cell Count (WBC) to Mean Platelet Volume ratio (WMR) with MACE was assessed in hospital. The patients were divided into two groups: Group A [MACE-positive] and Group B [MACE-negative]. Multivariate COX regression was performed to calculate odds ratio (OR).

Result: In the ROC curve analysis, WMR had the highest area under receiver operating characteristics curve and highest discriminative ability amongst all $\mathrm{CBC}$ parameters in predicting MACE , the cut-off value of WMR in the prediction of MACE was $7.65 \mathrm{~mm}$ (AUC $0.74,95 \%$ CI $0.645-0.835, \mathrm{p}<0.001)$. The NSTEMI group with dengan WMR $\geq 1118$ had a higher incidence of MACE than the group with WMR $<1118$ of 24 people $(70.6 \%)$ versus 10 people $(29.4 \%)$. WMR $\geq 1118$ is considered to predict the incidence of MACE with a sensitivity of $70.6 \%$, a specificity of $70 \%$, a negative predictive value (NPV) of $83 \%$ and a positive predictive value (PPV) of 53\%. Multivariate analysis showed that WMR $\geq 1118$ was an independent factor that could predict the occurrence of MACE during the hospitalization period (OR 10.49, 95\% CI 3.01-36.65, p<0.001). Conclusion: WMR is an inexpensive indicator, can be done easily and can become an independent factor to predict MACE during hospitalization in NSTEMI patient with OR 10.49.
\end{abstract}

Keyword : WMR, MACE, NSTEMI, ACS.

Yusrina Saragih et al/International Journal of PharmTech Research, 2018,11(4): 298-304.

DOI: http://dx.doi.org/10.20902/IJPTR.2018.11401 


\section{Introduction}

It has been estimated that 17.5 million death because of cardiovascular disease in $2012^{1}$. Around $80 \%$ of all this dead caused by heart attack and stroke, and three quarter incidence happened in countries with lowmoderate income ${ }^{1,2}$.Prevalence of Non ST-Elevation Myocardial Infarction (NSTEMI) encompass around 70\% of acute coronary syndrome (ACS) usually with older age and multiple comorbidities ${ }^{3}$. Even though heart failure and arrythmia seldom happens, patient wit NSTEMI had higher recurrence rate and worse prognosis in short and long term ${ }^{4}$.

ACS caused by atherosclerosis, which is accumulation of lipid and other substance that became plaque in coronary artery. This atherosclerotic plaque causes narrowing of coronary arteries that will disturb myocardial blood flow and causing myocardial ischemia ${ }^{5}$. If the plaque ruptured, thrombosis will happen caused by inflammatory process, which is thrombus formation and activation by platelet, leukocyte, and other inflammatory mediator and could cause total or partial occlusion of the coronary arteries and necrosis of myocardium $^{5,6}$. Because of that reason, inflammatory marker such as leukocyte and platelet can be used as prognosis parameter for predicting Major Adverse Cardiovascular Events (MACE) in ACS patient.

The effect of high leukocyte is closely related to complication such as ventricular arrythmia in early phase of ACS, reperfusion injury of the coronary arteries, and myocardial infarct size ${ }^{7}$ This is caused by released intracellular granule that contain enzyme and free radical or oxidant as a response to acute inflammation ${ }^{8}$. Platelet activation has an important role in the pathophysiology of ACS and myocardial infarct progression. This process happened after plaque ruptured that stimulate platelet activation and eventually form thrombus. Activated platelet will progress to ACS and will cause changes in shape and size of the platelet that can be assessed by Mean Platelet Volume (MPV) ${ }^{8,9}$. Platelet secrete important mediator for coagulation, thrombosis, and atherosclerosis progression ${ }^{10}$.

After analyzing those two parameter, author want to evaluate White Blood Cell Count e MPV Ratio (WMR) as a prognostic parameter for MACE during hospitalization in ACS especially NSTEMI patient.

\section{Method}

\section{Study Design and Population}

This prospective cohort study was carried out atHaji Adam Malik Hospital Medan (RSHAM) with approval from Komite Etik Penelitian Fakultas Kedokteran Universitas Sumatera Utara-RSHAM for ethical clearance.From October 2017 until April 2018,all patient who diagnosed as NSTEMI according to ESC diagnostic criteria such as acute angina accompanied by significant increase of cardiac enzyme without persistent ST segment elevation in two adjacent lead and without left bundle branch block ${ }^{11,12}$. Exclusion criteria including $2^{\text {nd }}$ and $3^{\text {rd }}$ degree AV block, cardiogenic shock (Killip IV), patient with other condition that become the primary cause of increased cardiac enzyme such as tachyarrythmia, decompensated heart failure not caused by ACS, Hypertensive crisis, several critical condition including sepsis, non cardiogenci shock, burn wound, myocarditis, Tako-Tsubo cardiomyopathy, aortic stenosis, pulmonary embolism, acute renal failure, coronary spasm, acute neurological condition (stroke, subarachnoid haemorrhage), patient that having cardiac surgery, hypo and hyperthyroidism, connective tissue disease (scleroderma, haemochromatosis), Rhabdomyolisis, also excluding patient with condition that could disturb Leukocyte and MPV value such as infection, septic, blood malignancy, antibiotics, severe bleeding, liver disease, and drugs usage (immunosuppressor agent and previous anticoagulation).

The outcomes of this study was major cardiovascular adverse events such as mortality, acute heart failure, malignant arrythmia, and cardiogenic shock. All patients were given standard treatment of NSTEMI in cardiology department at Haji Adam Malik Hospital.

After the inclusion criteria is fulfilled then the data such as patient characteristic was recorded by using study form, laboratory examination and transthoracal echocardiography was also done. Standard echocardiography measurement was done by the cardiology resident in charge in cardiac emergency and/or intensive cardiac care unit (CVCU/ICCU) within first 24 hour after admittance by using GE Vivid S6 Heart Probe Sector $3.50 \mathrm{MHz}$ in lateral decubitus position. Related coronary arteries was evaluated by using coronary 
angiography. Laboratory sample was obtained by using venous blood sample taken within 30 minutes after admission in cardiac emergency by clinical pathology staff and then complete blood analysis was done by using Hematology Analyzer Sysmex XP-300added with renal function test (urea and creatinin) lipid profile, blood glucose profile, Troponin I, and CKMB. Then all data were collected and analyzed.

\section{Statistical Analysis}

Statistical analysis was done by using statistic software. Categorical variable represented by total or frequency $(\mathrm{N})$ and percentage $(\%)$. Numerical variable represented by mean with standard deviation for data that distributed normally. Normality test for all numerical variable was done by using Kolmogorov-Smirnov test with $n>50$. Cut off point for numerical data was obtained by using ROC curve. Comparison between independent and dependent variable was done by using Pearson Chi Square.

Multivariate analysis from independent and dependent variable was tested by logistic regression. Variablethat had $\mathrm{p}$ value $<0,05$ in multivariate analysis would be shown as odds ratio (OR) with confidence interval 95\%. All statistical analyses were performed using SPSS, version 18.0 and $\mathrm{p}$ value $<0,05$ was considered as statistically significant

\section{Result}

Total study subject was 104 patient that fulfilled inclution and exclution criteria, 70 people $(67.3 \%)$ with MACE and 34 people(32.7\%) without MACE. From 34 with MACE, 26 people(76.5\%) were male and 8 people(23.5\%) werefemale. Mean age of study subject was 57 years old in MACE group and 54 years old in non MACE group, but this is not statistically significant $(\mathrm{p}>0.05)$.

From clinical parameter, there are significant difference in systolic blood pressure (SBP), diastolic blood pressure (DBP) and heart rate $(\mathrm{p}=0.001, \mathrm{p}=0.033, \mathrm{p}=0.001)$. higher heart rate and lower SBP and DBP was found in MACE group.

From risk factor variable, patients with MACE had higher smoking rate [28 (82.4\%) vs 31 (44.3\%) $(\mathrm{p}<0.001)]$ and higher rate of Diabetes Melitus [19 (55.9\%) vs $23(32.9 \%)(\mathrm{p}=0.025)]$ compared to without MACE group.

Other significant difference were found in Leukocye $\operatorname{count}(\mathrm{p}<0.001)$, glomerular filtration rate (GFR) (0.036), random blood glucose $(\mathrm{p}=0.001)$, fasting blood glucose $(\mathrm{p}=0.002)$, post prandial blood glucose $(\mathrm{p}=0.001), \mathrm{HbA1c}(\mathrm{p}=0.024), \mathrm{MPV}(\mathrm{p}=0.001)$, and White Blood Cell Count MPV Ratio (1283.2 \pm 304.5 vs $1020.6 \pm 313.9$, $\mathrm{p}<0.001)$.

Significant difference was also found in TIMI score $(\mathrm{p}=0.041)$, GRACE score $(\mathrm{p}=0.007)$, and number coronary lession ( $\mathrm{p}=0.001$ ), MVCAD was found with higher rate in MACE group which is 30 subject (88.3\%) compared to 40 subject (55.7\%) in non MACE group. (Table. 1)

Table1.Baseline Characteristic of Study Subject According to MACE

\begin{tabular}{|l|l|l|l|}
\hline Parameter & $\begin{array}{l}\text { MACE (-) } \\
\mathbf{n = 7 0}\end{array}$ & $\begin{array}{l}\text { MACE (+) } \\
\mathbf{n = 3 4}\end{array}$ & P value \\
\hline Sex (n, \%) & $\begin{array}{l}52(74.3) \\
\text { Male }\end{array}$ & $\begin{array}{l}26(76.5) \\
8(23.5)\end{array}$ & 0.809 \\
Female & $18(25.7)$ & $57 \pm 8$ & 0.195 \\
\hline Age (years old) & $54 \pm 10$ & $26.4 \pm 3$ & 0.218 \\
\hline BMI (kg/m $)$ & $25.6 \pm 3$ & $119 \pm 31$ & $0.001^{*}$ \\
\hline SBP (mmHg) & $136 \pm 21$ & $75 \pm 17$ & $0.033^{*}$ \\
\hline DBP (mmHg) & $81 \pm 11$ & $98 \pm 32$ & $0.001^{*}$ \\
\hline Heart rate(x/minutes) & $83 \pm 16$ & & \\
\hline Risk Factor (n, \%) & & $24(70.6)$ & 0.834 \\
Hypertension & $48(68.6)$ & $19(55.9)$ & $0.025^{*}$ \\
DM & $23(32.9)$ & & \\
\hline
\end{tabular}




\begin{tabular}{|c|c|c|c|}
\hline $\begin{array}{l}\text { Dyslipidemia } \\
\text { Smoking history } \\
\text { Family history }\end{array}$ & $\begin{array}{l}39(55.7) \\
31(44.3) \\
21(30)\end{array}$ & $\begin{array}{l}21(61.8) \\
28(82.4) \\
13(38.2)\end{array}$ & $\begin{array}{l}0.558 \\
<0.001^{*} \\
0.401\end{array}$ \\
\hline $\mathrm{Hb}(\mathrm{mg} / \mathrm{dL} \pm \mathrm{SD})$ & $15.7 \pm 16$ & $13.3 \pm 2$ & 0.399 \\
\hline Leukocyte $\left(10^{3} / \mathrm{uL} \pm \mathrm{SD}\right)$ & $9909 \pm 2836$ & $10284 \pm 3226$ & $<0.001 *$ \\
\hline Ureum $(\mathrm{mg} / \mathrm{dL} \pm \mathrm{SD})$ & $34 \pm 16$ & $28.5 \pm 12$ & 0.103 \\
\hline Creatinin $(\mathrm{mg} / \mathrm{dL} \pm \mathrm{SD})$ & $1.3 \pm 1.6$ & $1.1 \pm 0.4$ & 0.207 \\
\hline GFR $(\mathrm{mL} / \mathrm{min} / 1.73 \mathrm{~m} 2 \pm \mathrm{SD})$ & $71.1 \pm 30$ & $84.4 \pm 30$ & $0.036^{*}$ \\
\hline Random BG (mg/dL \pm SD) & $147 \pm 64$ & $206 \pm 109$ & $0.001 *$ \\
\hline fasting BG (mg/dL \pm SD) & $120 \pm 51$ & $166 \pm 91$ & $0.002^{*}$ \\
\hline Prandial BG (mg/dL \pm SD) & $152 \pm 60$ & $208 \pm 100$ & $0.001 *$ \\
\hline HbA1C $(\% \pm S D)$ & $6.8 \pm 1.9$ & $7.7 \pm 2.1$ & $0.024^{*}$ \\
\hline Total Cholesterol $(\mathrm{mg} / \mathrm{dL} \pm \mathrm{SD})$ & $180 \pm 46$ & $188 \pm 53$ & 0.404 \\
\hline Troponin $(\mu \mathrm{g} / \mathrm{L})$ & $1.58 \pm 3.6$ & $1.95 \pm 4.8$ & 0.69 \\
\hline CKMB (U/L) & $49 \pm 35$ & $55 \pm 64$ & 0.56 \\
\hline TG (mg/dL \pm SD) & $145 \pm 57$ & $150 \pm 78$ & 0.701 \\
\hline LDL (mg/dL \pm SD) & $120 \pm 43$ & $133 \pm 50$ & 0.166 \\
\hline HDL $(\mathrm{mg} / \mathrm{dL} \pm \mathrm{SD})$ & $36.28 \pm 10.42$ & $36.3 \pm 11.84$ & 0.997 \\
\hline MPV (fL) & $9.8 \pm 0.73$ & $10.3 \pm 0.7$ & $0.001 *$ \\
\hline WMR & $1020.6 \pm 313.9$ & $1283.2 \pm 304.5$ & $<0.001 *$ \\
\hline Neutrofil $\left(10^{3} / u_{L} \pm\right.$ SD $)$ & $30.5 \pm 30.3$ & $30.4 \pm 32.2$ & 0.996 \\
\hline Limfosit $\left(10^{3} / \mathrm{uL} \pm \mathrm{SD}\right)$ & $9.8 \pm 10.6$ & $9.7 \pm 12.3$ & 0.956 \\
\hline NLR & $3.6 \pm 2.2$ & $4.6 \pm 5.2$ & 0.168 \\
\hline EF (\%) & $51.4 \pm 12.9$ & $42.1 \pm 12.1$ & 0.562 \\
\hline $\begin{array}{l}\text { TIMI } \\
<3 \\
>3\end{array}$ & $\begin{array}{l}28(40.6) \\
42(59.4)\end{array}$ & $\begin{array}{l}8(23.5) \\
26(76.5)\end{array}$ & $0.041^{*}$ \\
\hline $\begin{array}{l}\text { GRACE } \\
<109 \\
>109\end{array}$ & $\begin{array}{l}51(72.9) \\
19(27.1)\end{array}$ & $\begin{array}{l}20(58.8) \\
14(41.2)\end{array}$ & $0.007 *$ \\
\hline $\begin{array}{l}\text { Coronary Lesion } \\
\text { SVCAD } \\
\text { MVCAD }\end{array}$ & $\begin{array}{l}30(42.9) \\
40(57.1)\end{array}$ & $\begin{array}{l}4(11.7) \\
30(88.3)\end{array}$ & $\begin{array}{l}0.001 * \\
0.004 *\end{array}$ \\
\hline
\end{tabular}

By using ROC curve, the Area Under the Curve (AUC) value of parameter White Blood Cell CountMPVRatio (WMR) can be found, which will show the ability of WMR to predict MACE during hospitalization for NSTEMI patient. In this study, we found AUC 0.74 with $p$ value $<0.001$ that shows that WMR value is clinically significant as MACE predictor during hospitalization in NSTEMI patient. With cut-off point $\leq 1118$ can predict MACE with sensitivity $71 \%$ and specificity $70 \%$. (Table 2 ) 


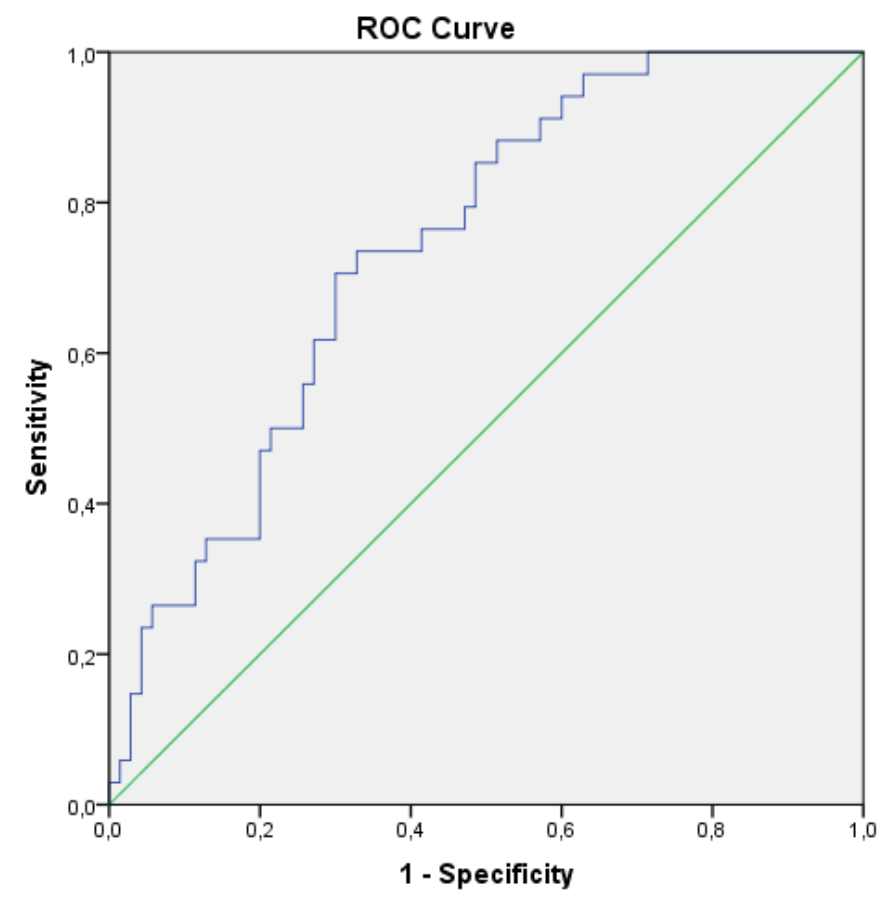

Picture 1. ROC Curve for WMR to predict MACE during hospitalization

Table 2.Results from ROC analysis

\begin{tabular}{|l|l|l|l|l|l|}
\hline Titik Potong & Sens & Spes & AUC & P value & 95\% CI \\
\hline $\mathbf{1 1 1 8}$ & $71 \%$ & $70 \%$ & 0.74 & $<0.001$ & $0.645-0.835$ \\
\hline
\end{tabular}

From 104 study subjects, 45 subjects have WMR $\geq 1118$ and 59 subjects have WMR $<1118$. Subjects with WMR $\geq 1118$ group had higher MACE compared to WMR $<1118$ group [24 (70.6\%) vs $10(29.4 \%)$ ]. 49subject $(70 \%)$ in WMR $<1118$ group and 21subject (30\%) in WMR $\geq 1118 \mathrm{~mm}$ group did not have MACE. (Table3)

WMR value $\geq 1118$ can predict MACE with sensitivity $70.6 \%$, spesificity $70 \%$, negative predictive value (NPV) $83 \%$ andpositive predictive value (PPV) $53 \%$.

Table3.Diagnostic test for WMR cut off point

\begin{tabular}{|l|l|l|l|l|l|l|l|l|}
\hline \multirow{2}{*}{ LMR } & MACE & Total & $\begin{array}{l}\text { P } \\
\text { value }\end{array}$ & Sens & Spes & NPV & PPV \\
\cline { 2 - 7 } & Yes & No & 45 & $<0.001$ & $70.6 \%$ & $70 \%$ & $83 \%$ & $53 \%$ \\
\hline$<1118$ & 24 & 21 & $45 \%$ & & & & & \\
& $(70.6)$ & $(30)$ & $(43.3)$ & & & & & \\
\hline$<1118$ & 10 & 49 & 59 & & & & & \\
& $(29.4)$ & $(70)$ & $(56.7)$ & & & & & \\
\hline Total & 34 & 70 & 104 & & & & \\
& $(100)$ & $(100)$ & $(100)$ & & & & \\
\hline
\end{tabular}

Multivariate analysis in this study showed that there were three independent factor that could predict MACE during hospitalization which is smoking history[OR $5.57(1.67-18.67), \mathrm{p}=0.005$ ], $\mathbf{S B P}<\mathbf{1 0 0}$ [OR 11.63 (1.86-72.71), $\mathrm{p}=0.009$ ] and $\mathbf{W M R} \geq 1118$ [OR 10.49 (3.01-36.65), $\mathrm{p}<0.001]$ (Table4). 
Table 4.Multivarite Logistic Regression Analysis of WMR to Predict MACE in NSTEMI Patients during Hospitalized

\begin{tabular}{|l|l|l|l|l|}
\hline Parameter & P value & OR & Lower & Upper \\
\hline Smoking History & 0.005 & 5.57 & 1.67 & 18.67 \\
\hline SBP $<\mathbf{1 0 0}$ & 0.009 & 11.63 & 1.86 & 72.71 \\
\hline LMR $\geq \mathbf{1 1 1 8}$ & $<0.001$ & 10.49 & 3.01 & 36.65 \\
\hline
\end{tabular}

\section{Discussion}

This prospective cohort study showed that increasing of WMR was related to MACE during hospitalization in NSTEMI patient. Smoking history and SBP $<100 \mathrm{mmHg}$ was also found to be independent predictor for MACE. WMR was also found to be a strong predictor for increased MACE and had higher value compared to other complete blood analysis component to predict outcome during hospitalization.

Older studies from MukhtarZ (1994) showed that leukocyte value was a strong predictor for MACE and AMI patient with initial leukocyte value $>15.000 / \mu 1$ had higher risk for left ventricle dysfunction as much as $4 \mathrm{x}$ higher, $4 \mathrm{x}$ higher mortality risk and $2 \mathrm{x}$ higher ventricular arrythmia (VT/VF) risk compared to initial leukocyte value $<15.000 / \mu$ lwith $95,9 \%$ sensitivity ${ }^{13}$. Leukocyte could cause delayed microvascular reperfusion, increased free radical and proteolytic enzyme which will induce hypercoagulability state and activate tissue factor that will increase thrombus formation and infarct size. If those marker added with $M P V$ that showed higher platelet size that had higher thrombogenicity, this could cause larger occlusion in coronary arteries. Because of that reasoning, a new parameter called WMR was found.

This study match the previous study by Dehgani MR et al (2015) which found that WMR value is a stronger predictor compared only leukocyte or only MPV. Dehghani et al also found that average WMR value was haigher in MACE group compared to non MACE group(863.2 vs731.5 with $\mathrm{p}=0.001)$, but average WMR value in Dehghani studies were lower compared to this study ${ }^{14}$. Variation in the WMR value possibly caused by several metabolic factor that exist in the study subject, because Leukocyte and MPV level can be affected by several factor such as Metabolic Syndrome, medication usage or several other factor.

WMR value $\geq 1118$ considered optimal to predict MACE according to ROC curve with sensitivity $71 \%$ and specificity $70 \%$. Study subject with WMR value $\geq 1118$ had higher MACE compared to WMR value < 1118 which is 24 subjects(70,6\%) vs10subjects (29.4\%). Cut off point by Arsalan MA et al (2017) that comes from ROC curve were $>1068.75$ as an optimal cut off point to predict MACE with lower sensitivity and specificity comapared to this study which is $68.3 \%$ and $63,7 \%$ (AUC $0.734, \mathrm{p}<0.001,95 \%$ CI $0.656-0.812$ ). Other studies also found lower optimal cutoff point compared to this study which is $>750^{15}$. Possible cause of variability in WMR cut-off point is because of difference in population where Arsalan et al (2017) include all patient with ACS and Dehghani et al (2015) include patient with metabolic syndrome also possibly caused by difference in Hematology Analyzer device and calibration ${ }^{14,15}$.

After multivariate analysis has done, we found three independent factor that could predict MACE during hospitalization for NSTEMI patient, which is Smoking History[OR 5.57 (1.67-18.67), p=0.005], $\mathbf{S B P}<\mathbf{1 0 0}[\mathrm{OR} 11.63$ (1.86-72.71), $\mathrm{p}=0.009$ ] and $\mathbf{W M R} \geq \mathbf{1 1 1 8}$ [OR 10.49 (3.01-36.65), $\mathrm{p}<0.001]$.

\section{Study Limitation}

There are several limitation in this study such as lower number of study sample in this study as opposed to previous study and this study is only done in one centre therefore, further study needed with larger sample size.In this study MACE observation was only done during hospitalization meanwhile WMR value as a predictor usually done in for longer period of time such as 30 days or longer there longer follow up needed.This study also did not compare WMR value in all ACS patient, therefore further studies needed to find correlation between WMR value in this type of population and also revascluarization during hospitalization was not considered as outcome modificator so further studies needed to find correlation between intervention with MACE. 


\section{Conclusion}

WMR is a cheap indicator, easy to be done, and can become a strong independent factor to predict MACE during hospitalization for NSTEMI patient compared to other complete blood parameter.

\section{References}

1. World Health Organization. 2014. Global Health Estimates: Deaths by Cause, Age, Sex And Country, 2000-2012. Geneva: World Health Organization.

2. World Health Organization. 2016. HEART: Technical Package for Cardiovascular Disease Anagement in Primary Health Care. Publication Data, Geneva: World Health Organization.

3. Departemen Kesehatan Republik Indonesia. 2008. RisetKesehatanDasar. Jakarta: Badan Penelitiandan Pengembangan Departemen Kesehatan Republik Indonesia.

4. Braunwald, E., Bonow, R. O., Mann, D. L., . . .. 2012. Braunwald's Heart Disease: A Textbook of Cardiovascular Medicine. Edisi 9. Philadelphia: Elsevier Saunders.

5. Lilly, S. L. Atherosclerosis In: Pathophysiology of Heart Disease 4th ed., Lippincot Williams \&Wilins, Boston, 2007:118-140

6. trom, J.B. and Libby, P., 'Atherosclerosis', in Lilly, L.S. (ed.) Pathophysiology of Heart Disease: A Collaborative Project of Medical Students and Faculty, 5th edition, Baltimore: Lippincott of Williams and Wilkins, 2011.

7. Pereg, D., Berlin, T., \& Mosseri, M. (2010). Mean platelet volume on admission correlates with impaired response to thrombolysis in patients with ST-elevation myocardial infarkion. Platelets, 21(2), 117-121. doi:10.3109/09537100903487599.

8. Bath, P. M., \& Butterworth, R. J. (1996). Platelet size: measurement, physiology and vascular disease. Blood Coagulation \& Fibrinolysis, 7(2), 157-161. doi:10.1097/00001721-199603000-00011.

9. Huczek, Z., Kochman, J., Filipiak, K. J., Horszczaruk, G. J., Grabowski, M., Piatkowski, R., . . ., \& Opolski, G. (2005). Mean platelet volume on admision predicts impaired reperfusion and long term mortality in acute myocardial infarkion treated with primary percutaneous coronary intervention. Journal of the American College of Cardiology, 46(2), 284-290. doi:10.1016/j.jacc.2005.03.065.

10. Gawaz, M., Langer, H., \& May, A. E. (2005). 'Platelet in inflmation and atherogenesis'. The Journal of Clinical Investigation, 115(12), 3378-3384. doi:10.1172/JCI27196.

11. Irmalita, Juzar DA, Andrianto, Setianto BY et al.,PedomanTatalaksanaSindromKoronerAkut. EdisiKetiga. Jakarta: PerhimpunanDokterSpesialisKardiovaskular Indonesia, 2015.

12. Amsterdam, E. A., Wenger, N. K., Brindis, R. G., Casey, D. E., Jr., Ganiats, T. G., Holmes, D. R., Jr., . ., \& Zieman, S. J. (2014). AHA/ACC Guideline for the Management of Patients With Non-STElevation Acute Coronary Syndromes: Executive Summary. Circulation, 130(25), 2354-2394. doi:10.1161/CIR.0000000000000133.

13. Mukhtar Z.,Makna Klinisdan Prognosis Leukositosispada Infark Miokard Akut. Tesis Profesillmu Penyakit Jantung FK UI. 1994.

14. Dehghani, M. R., Rezaei, Y., \& Taghipour-Sani, L. (2015). White blood cell count to mean platelet volume ratio as a novel non-invasive marker predicting long-term outcomes in patients with non-ST elevation acute coronary syndrome. Cardiology Journal, 22(4), 437-445. doi:10.5603/CJ.a2015.0015.

15. Adam, A. M., Rizvi, A. H., Haq, A., Naseem, R., Rehan, A., Shaikh, A. T., \& Lashari, M. N. (2018). Prognostic value of blood count parameters in patients with acute coronary syndrome. Indian Heart Journal, 70(2), 233-240. doi:10.1016/j.ihj.2017.06.017.

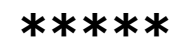

